\title{
Dagmar Kusá
}

Bratislava International School of Liberal Arts

\section{The Born Frees as Assertive Citizens?}

\section{Student Protests and Democratic Prospects in South Africa}

\begin{abstract}
Massive student protests in South Africa in the past few years, largest since the times of the anti-apartheid struggles, raised several questions for political scientists. Are we witnessing a generational change? Or are they a sign of a broader global shift towards "assertive citizenship" present in advanced democracies and democratizing countries? To answer these questions, this paper examines the levels of political support and nature of political participation among the young generation.

The paper also points out that generational change is not immediately visible in public opinion polls but is a process of a gradual narrative construction. Protests brought with them a challenge to the founding narrative of a united Rainbow Nation and reconciliation with the past, leading to a fracture in democratic stability. For the democratic project to succeed, it is essential that the national project in South Africa does not fall apart.
\end{abstract}

Keywords: South Africa, post-apartheid, political participation, political support, identity, generational change, transition

\section{Introduction}

The past few years in South Africa were marked by large waves of student protests that have captured the public imagination and discourse. \#RhodesMustFall called for decolonization of South African universities' curricula, \#FeesMustFall for reduction of fees, \#OpenStellebosch, \#DisruptingWhiteness, \#AfrikaansMustFall and several other campaigns called for more equality in access to education and language policies, and introduced several new topics as challenging the patriarchy or LGBTQ rights. Black South African students felt that the political leaders, including the stalwarts that embodied the regime change, let them down and forgot them in the transition process. Many of them maintained that the glaring socioeconomic disparities between racial groups are a continuation of the apartheid and that the Rainbow Nation is but a myth. 
Social scientists are therefore interested in whether the "Born Frees", a generation born after the fall of the apartheid, are significantly different in their attitudes and beliefs than the older generations.

\section{Hypothesis}

Public opinion polls as recent as 2017 show that there is no significant difference between the Born Frees and the older generations. However, they take part in political life in more contentious ways, utilizing protests, strikes, boycotts. Since they maintain high levels of support for democracy, and are critical of institutions and political leaders, this trend is consistent with a broader global trend of a rise of "assertive citizenship". If the analysis ended there (as it frequently does), it would be tempting to conclude that no generational change is taking place in South Africa, rather that we see an overall shift in the nature of democratic citizenship, which is taken to be a good omen for democratic effectiveness. But public opinion data alone cannot capture the process of construction of generational narratives. The protesting Born Frees are talking a different talk. Grievances raised by the students stirred the political discourse. It was the emotions stemming from a long-term humiliation of inequality in wealth, status, access, life opportunities, mobilized this group of young people towards action. Their voices sound a serious challenge to the founding narrative of the new regime, including the way the political nation is imagined.

\section{Political Support}

When they developed the model of a civic culture in early 1960s, Almond and Verba maintained that some amount of apathy and significant amount of allegiance to political institutions and leaders is essential for the stability of democracy (Almond \& Verba, 1963). The democratic civic culture worldwide has grown since far more critical toward democratic institutions and leaders, and more assertive in political participation (Norris, 1999; Dalton \& Welzel, 2014; Inglehart \& Catterberg, 2002). Political support, expressed as trust in the political leaders and institutions and belief in their legitimacy, is crucial for the consolidation of democracies. Conceptualized by David Easton (1975) and further advanced by Pippa Norris (Norris, 1999), political support is differentiated on a spectrum ranging from diffuse to specific. Support for political community is the most diffuse type of support, related to the feelings of national pride, sense of belonging to a political community. It is also the most basic type of support, as it underlies the whole political regime (Easton, 1975, p. 445). Support for the core regime principles captures the core values, such as the support for democracy. Towards the specific end of the spectrum lies evaluation of regime performance (how democracy is working), support for regime institutions (parliaments, government, judiciary, political parties, etc.), and support for political actors, authorities (Norris, 1999, pp. 10-12). Political culture studies often take the basic support for a political community 
as a given. It is considered the most stable and slow to change, thus focus is given to the more specific types of political support.

Factors that contribute to political support vary culturally. But some factors tend to be central anywhere. Socialization, education, and day to day experience with political institutions are time and again proven to be the key factors (Almond \& Verba, 1963; Diamond, 1999; Ramphele, 2010). Mishler and Rose share the assumption that trust is learned and conditioned by experience (Mishler \& Rose, 2001, p. 37). It is thus dependent on lifelong learning, composed of pre-political influences, reinforced or revised based on experience with institutions, evaluations of political performance (Mishler \& Rose, 2001, p. 37-38). Trust in political institutions can be earned by effectively addressing public priorities, transparent conduct, safeguarding of individual freedoms, and policies that bring economic progress. However, if the performance falters over a long period of time, even the more stable pool of trust in a political community can erode.

\section{Methodology}

This paper applies the Eastonian elements of political support outlined above on the orientations of the age group between 18-25 years of age. It is impossible to conclude with certainty whether we are witnessing significant shifts in political attitudes of the Born Free generation, as most of the surveys are preceding the time of the peak of the student protests. The data available from the most recent public opinion surveys - Afrobarometer, and the South African Reconciliation Barometer surveys - are used to map political support of the Born Frees. These are representative nation-wide surveys, which use a clustered, stratified, multi-stage, area probability sample, to accurately represent geographical areas, ethnic and language groups, and racial categories. However, interviews with the former anti-apartheid struggle leaders, activists, and student protesters show that there is a widely shared perception that the past few years of student protests are an indication of a generational divide. To map the discourse of the day and its perception by different communities, personal interviews were conducted in the area of Cape Town and Johannesburg.

\section{Who are the Born Frees? \\ Scrambling Into the Middle Class}

South Africa's population is demographically very young. Two thirds of its population are under the age of 35 (Nyoka \& Lekalake, 2015). Those that were born at the time of the fall of the apartheid regime were growing up in a qualitatively different environment from that of their parents or grandparents, defined by issues that are central to most transition processes - economic constraints accompanying transition, heightened by the financial crisis of 2008, very high unemployment among the youth, social and economic inequality, unequal access and low quality of education. 
It is not surprising that the South African Born Frees consistently identify unemployment as the most serious problem they are facing (Nyoka \& Lekalake, 2015, p. 1). Same source points out that while $95 \%$ of young people (18 to 35 years of age) have access to some education, only $11 \%$ of the respondents have access to higher education, and chances vary greatly by race and location in the city or countryside (Nyoka \& Lekalake, 2015). South Africa's unemployment reached $27.7 \%$ in 2017, and the rate of unemployed young people (between the ages of 15 and 34) climbed up to 38.4\% (Quarterly Labour Force Survey Quarter 1 2017,2017), and even higher if discouraged job seekers are added (above $50 \%$, compared to $17 \%$ in the age group of 35-64). Only $8 \%$ of the White South Africans are unemployed. $60 \%$ of Black South Africans live below the poverty line, while poverty touches only $4 \%$ of the white population (Swartz, 2016,p.xx). Thus, the young Black South Africans, and especially young black women (reaching a staggering $52.5 \%$ unemployment rate), are the most impacted population group (Statistics SA, 2017). It is a population group that is experiencing widespread exclusion from equal life opportunities. The vastly unequal distribution of economic assets within the South African society is a heritage of the apartheid. The World Bank named it the world's most unequal society (The World Bank, 2018). The ratio of private net ownership between White and Black South Africans is 13:1 (Southall, 2016, p. 165).

Black South Africans thus have a dramatically different starting point when they face adolescence from their white counterparts. While there existed small pockets of a black middle class in the previously "independent" Bantustans (areas designated for the Black African population that were granted self-government), most of the black middle class is genuinely new. This also means that there are few assets to pass down, and those that are must be normally shared with a broad network of relatives. Trans-generational poverty also means that current young adults lack important life skills in basic home economic management and planning.

\section{Education Deficit and the Ghosts of Racialism}

The state of the education system is perceived as one of the key failures in the South Africa's transition. Mass protests in the past few years in South Africa revolve around the questions of inequalities in access to education and education policies and content. Rising fees, unaffordable for many middle class Black South African students who did not qualify for government support grants, served as a trigger towards a protest movement. They stirred the accumulated frustration and humiliation stemming from lasting inequality.

South Africa faced a formidable task to reform the education system from being racially and regionally separated into parallel school systems of vastly different quality into one national education system (Asmal, 2011). The Council on Higher Education (CHE) figures show that there has been success in making higher education available - enrollment in tertiary public education institutions rose from 473,000 students in 1993 to 975,837 in 2016, 
$58 \%$ of which are women (CHE, 2018). Racial composition of students was a particularly grave challenge. In 1994, 75\% of young White adults (between 18 and 25 years of age) participated in higher education, compared to only $5 \%$ of young Black South Africans. This proportion grew, reaching $16 \%$ of Black South African (making up $72 \%$ of the student body) and $14 \%$ of colored youths in public higher education (see Chart 1 below). Only 77\% of black students successfully complete their undergraduate studies and only $66 \%$ post-graduate studies, compared to $86 \%$ and $81 \%$ respectively for the white students. Furthermore, nearly half $(1,299)$ of 3,000 senior management staff at the universities are white, compared to 893 black. (CHE, 2018, p. 45). Proportions of non-white minorities and women among academic staff decline with every reached level of education.

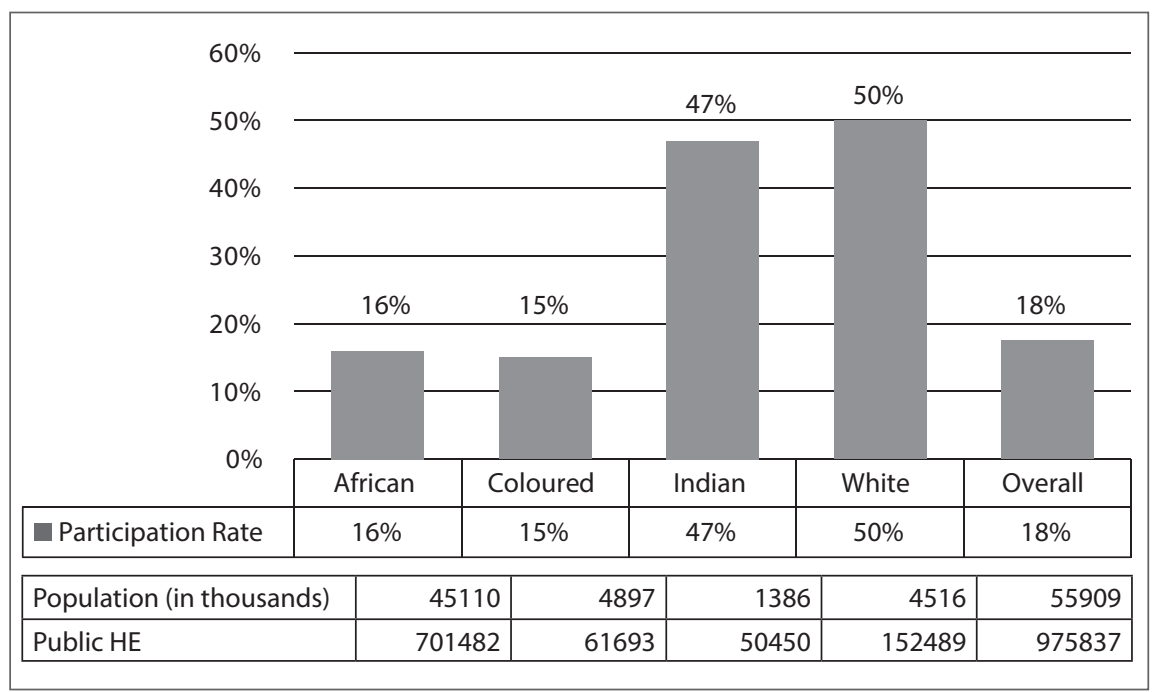

Figure 1: Participation in Tertiary Education (\%)

Source: Vital Stats: Public Higher Education in 2016 (CHE, 2018).

Most reforms focused on quantitative changes - getting students into the system, getting more funding for formerly disadvantaged schools and students. Less attention was paid to the quality of education, which is alarmingly low in South Africa. This is exacerbated by the languages of instruction - the elite universities operate in Afrikaans and English (in unequal measures), leaving education in the remaining nine official languages on the periphery.

There was a 57\% increase in tuition fees from 2008 to 2013 (CHE, 2018). Rapid influx of the black students into the higher education system made the social disparities more and more visible. Frustration, sense of powerlessness and humiliation experienced by the first-time university students led to the symbolic gestures of dissent at formerly white, high achieving universities, and got the ball of the protests fully rolling in 2015. 
Education system is also faltering in its mission of socializing future young adults into democratic citizenship through conscientious accounting with the past in its curricula. History as a subject has been folded into human and social sciences, and is voluntary past the age of 16 . When the transition process took off, the mainstream narrative was dominated by the theme of reconciliation and nation-building. University teaching staff remained largely white, statues, buildings, symbols of the previous era survived intact. Students have little access to diverse accounts of the past beyond the dominant narrative, says Helen Scanlon, founder of the University of Cape Town's Justice and Transformation Programme. Critical voices are missing, and students experience a very different reality from what they learn in the classroom (pers. interview, January 23 2017, UCT, Cape Town). Whether out of a sense of shame, or in earnest attempt to protect their children and spare them of pain, parents most often avoid the topic of the past as well. And so "students such as Maxwele, or Chikane (who were among the leaders of the protests) had little context for the persistence of race in their daily experience. Initially, they would interpret the experiences personally. When they finally discovered black history and identity, the lateness of the discovery made them angry" (Fairbanks, 2015).

\section{Support for Political Leaders and Institutions}

In public opinion polls, the Born Frees do not differ in their political attitudes from the previous generations. Rather than a significant generational divide, there are slight differences between all age cohorts. Just like their older peers, they trust democracy, yet mistrust political leaders and institutions. As young people anywhere, they are less likely to vote, but the Born Frees are interested in politics (51\% of $18-25$ years old is somewhat or very interested in public affairs). They do, however, loom as a source of potential change when it comes to the choice of a political party - traditional loyalty towards the African National Congress (ANC), the long-time leader of the anti-apartheid struggle and political home of Mandela's transitional government, has been weakening, although it is celebrating somewhat of a comeback since President Cyril Ramaphosa replaced Jacob Zuma in 2018.

Due to corruption scandals from top to local level, infighting within, favoritism and embezzlement, the support for the African National Congress (ANC), the party which is at the helm since 1994, was dwindling. By 2015, membership fell by 36\% (Johnson, 2017, p. 253) and it has met with the weakest results in local elections in 2016.

ANC's decline was partly also due to the failure to engage the Born Frees, many of whom will be taking to the election polls for the first time in 2019. This generation does not have the same loyalty to the ANC as the previous generations. Their evaluation of the political parties is based on their life experience, which has little connection to the ANC's symbolic status of the anti-apartheid struggle leader. High unemployment, faltering educational reform, corruption scandals, and the aging leadership of the party contribute to their turn- 
ing away from the ANC. Afrobarometer data from 2014/2015 show that $27 \%$ of youth (15 to 29 years of age) do not feel close to any political party as opposed to only $16 \%$ of those above 50 years of age. They are also less likely to vote for the ANC - 39\% of young people who feel closeness to any political party identified the ANC versus almost $50 \%$ of those in the oldest age group. The ANC had to contend for the first time with two parties growing in popularity: the historically predominantly white Democratic Alliance (DA), which also boasts anti-apartheid struggle legacy, and the new kid on the block: the Economic Freedom Fighters (EFF), established by the disenchanted young runaway cadres from the ANC. The DA, as Max du Preez observes, has to "struggle with its white "neoliberal" roots and character", but is succeeding in attracting young black leaders (du Preez, 2013, p. 275) and was gaining traction also among the young voters (16\% of young voters would vote for DA if there were presidential elections tomorrow, as opposed to 5.7\% in the year 2005) (Afrobarometer R3-6). The new presidency has swayed support back toward the ANC in 2018, unfortunately the survey does not break the data down by age groups.

Table 1: Closeness to Political Party

Do you feel close to any political party?

\begin{tabular}{llllll}
\hline & Total & Age & & & \\
\cline { 3 - 6 } & & $\mathbf{1 5 - 2 9}$ & $\mathbf{3 0 - 4 9}$ & $\mathbf{5 0 +}$ & Don't know \\
\hline No, not close to any party & $22.1 \%$ & $\mathbf{2 7 . 3} \%$ & $21.2 \%$ & $16.1 \%$ & $28.5 \%$ \\
\hline Yes, feels close to a party & $72.7 \%$ & $\mathbf{6 8 . 9} \%$ & $72.8 \%$ & $78.5 \%$ & $60.0 \%$ \\
\hline
\end{tabular}

Source: adapted from Afrobarometer R6 2014/2015 online data analysis

Table 2: Party Identification

Which party is that?

\begin{tabular}{lllllc}
\hline & Total & Age & & & \\
\cline { 3 - 6 } & & $\mathbf{1 5 - 2 9}$ & $\mathbf{3 0 - 4 9}$ & $\mathbf{5 0 +}$ & Don't know \\
\hline African National Congress (ANC) & $44.5 \%$ & $\mathbf{3 9 . 3 \%}$ & $45.8 \%$ & $49.4 \%$ & $53.1 \%$ \\
\hline Democratic Alliance (DA) & $13.4 \%$ & $\mathbf{1 2 . 1 \%}$ & $13.5 \%$ & $15.2 \%$ & - \\
\hline Economic Freedom Fighters (EFF) & $6.7 \%$ & $\mathbf{1 1 . 6 \%}$ & $5.2 \%$ & $2.5 \%$ & - \\
\hline
\end{tabular}

Source: adapted from Afrobarometer R6 2014/2015 online data analysis

Table 3: Vote for Which Party?

"If presidential elections were held tomorrow, which party's candidate would you vote for?"

\begin{tabular}{llllll}
\hline & Total & Age & & & \\
\cline { 3 - 6 } & & $\mathbf{1 5 - 2 9}$ & $\mathbf{3 0 - 4 9}$ & $\begin{array}{l}\mathbf{5 0} \text { and } \\
\text { more }\end{array}$ & Don't know \\
\hline African National Congress (ANC) & $48.3 \%$ & $\mathbf{4 6 . 3 \%}$ & $48.8 \%$ & $50.0 \%$ & $78.6 \%$ \\
\hline Democratic Alliance (DA) & $17.1 \%$ & $\mathbf{1 6 . 2 \%}$ & $17.3 \%$ & $18.3 \%$ & \\
\hline Economic Freedom Fighters (EFF) & $9.3 \%$ & $\mathbf{1 5 . 6 \%}$ & $7.9 \%$ & $3.1 \%$ & \\
\hline
\end{tabular}

Source: Afrobarometer R6 2014/2015 online data analysis 
Students tie grievances about socioeconomic disparities to the massive display of corruption. Calls for free education often harken unto the billions of ZAR embezzled by the new ruling and business elite as well as the surviving corporate elite from the times of the apartheid.

The President Jacob Zuma, the key figure of the post-apartheid corruption stories, has amassed 783 corruption charges against him to date (Johnson, 2017, p. 251) and is facing trials. The greatest corruption scandals were brought to light by the former Public Protector Thuli Madonsela in two major reports that changed the nature of the game - Secure in Comfort on the president's private luxurious residence expansion financed fraudulently from public funds, and The State of Capture, documenting the capture of the key strategic positions by corporate interests (Gqubule, 2017). Their publication and the preceding student protests contributed towards the spread of the protests from the universities to broader public, utilizing the appeal of the hashtag of the student movements to launch \#ZumaMustFall and \#UniteBehind campaigns calling for accountability and ousting of the President. However, not age, but race is a decisive factor in the amount of support he enjoyed. As Figure 2 shows, the level of distrust varied most significantly by race. The President was most supported by the Black Africans and the Coloured population, and is overwhelmingly mistrusted by the White and South Asian population. After the difficult initial 100 days in the office, the new President Cyril Ramaphosa is enjoying a high level of support, reaching 73\% (Ipsos, 2018b).

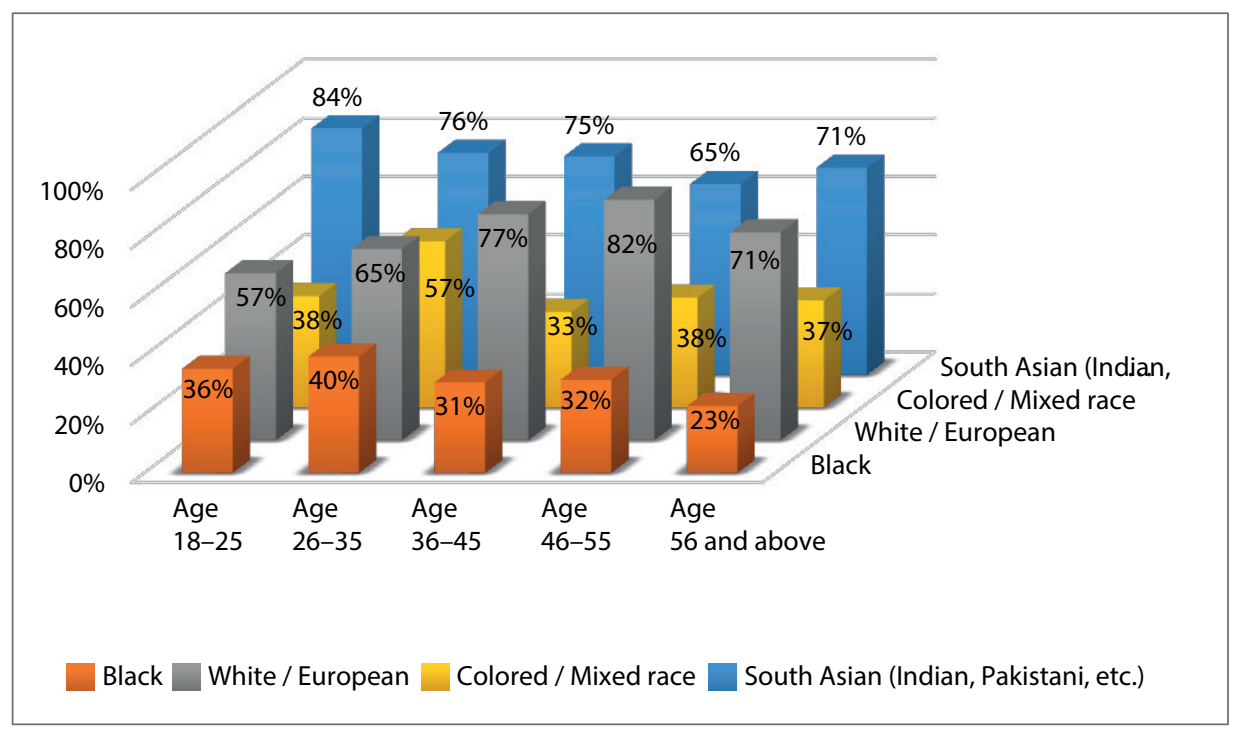

Figure 2: Proportion of those who do not trust the President at all by age and race Source: adapted from Afrobarometer Online Survey R6 2014/2015 
The level of trust in the national parliament has been equally low, likely because of its inability to hold the former President accountable (Potgieter \& Govender, 2016, p. 2). All age groups distrust the parliament between 24 to $30 \%$, with rising proportions of confidence with increasing age (still reaching only $21 \%$ of full trust in the oldest generation). When race is added, generational differences melt away. Again, the White and South Asian South Africans distrust the parliament in much greater proportions (47\% and 55\% respectively) than the black citizens (22\%). There is an apparent divide when it comes to residence. "[C] itizens who tend towards distrust or show skepticism in institutions (such as the president, parliament, government ministers or the ANC) are more likely to live in urban centers and larger towns. They are also more likely to be older, better-educated citizens and with higher incomes. On the other hand, trustful citizens are more likely to be Black African, live in rural areas, younger, less educated and poor" (Potgieter \& Govender, 2016).

\section{Upholding the Rule of Law}

Progressive liberal Constitution, strong and independent courts of law, and robust civil society are the backbone of the South African society. The Constitution enshrines the principle of non-racialism and individual human rights that serve as the building blocks of the South African vision of a democratic future. During the student protests, the Constitution was often challenged by the student leaders as an outcome of negotiation and compromise, perceived as a sell-out of the goal of emancipation of the Black population for a share of power with the former apartheid government. However, the student leaders' views do not seem to be representative of their generation as a whole, which perceives the importance of the Constitution to be more significant than the generation of their parents (58\% versus $51-54 \%$ ). $70 \%$ of all South Africans feel that the Constitution is important (and over 50\% regard it as very important), although older generations value it significantly more (Potgieter \& Govender, 2016, p. 1), appreciative of the change it represented in their lives.

The Truth and Reconciliation Commission (TRC) was another important institution established by the Interim Constitution. It held the promise of transition and healing, building up of a united nation. It is still appreciated by $57 \%$ of all South Africans. The public nature of this process of accounting with the past and healing that it offered to the victims of gross human rights violations has shaped the discourse on reconciliation in a remarkable fashion. To most, reconciliation means forgetting the past and moving on (43\%), and forgiveness among racial groups (33\%). These proportions do not vary significantly among racial groups or ages (only the age group of 35-44 years of age gives more emphasis to forgiveness (37\%), likely as a result of direct experience of the TRC in their formative years) (Afrobarometer R6, 2014/2015 online analysis). According to the Afrobarometer survey, most, and especially young people, feel race relations have gotten better since the beginning of the transition (particularly strong among the white population, where 55\% believe they got better or much better, another $18 \%$ feel they stayed the same). 

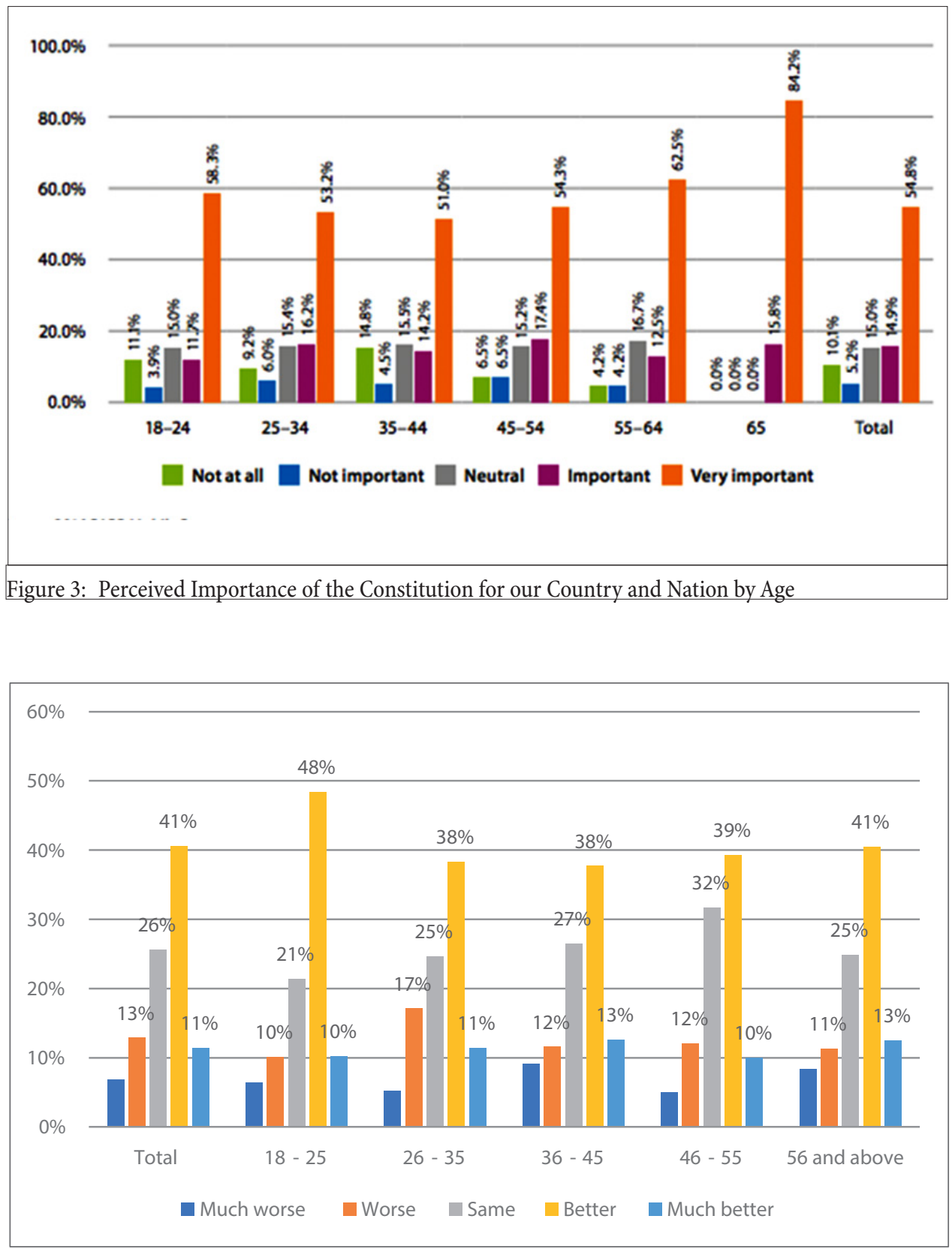

Figure 4: Change since 1994: Race Relations

Source: Afrobarometer R6 2014/2015 online analysis. 


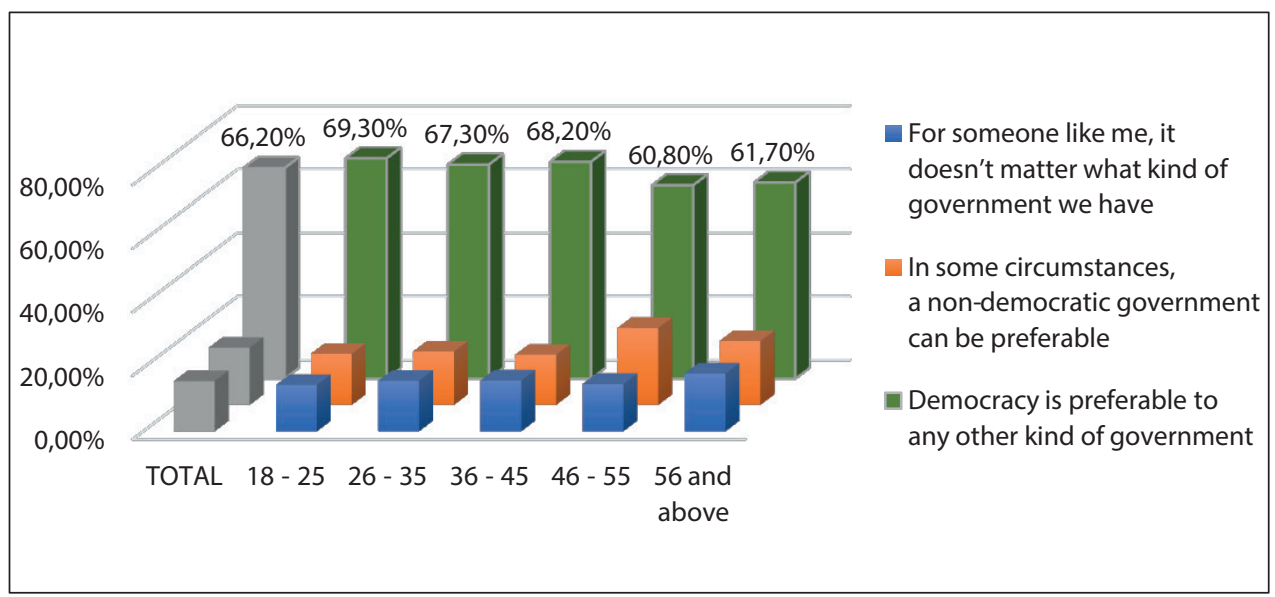

Figure 5: Support for Democracy by Age

Source: Afrobarometer Online analysis R6 (2014/2015).http://www.afrobarometer.org/online-data-analysis/ analyse-online

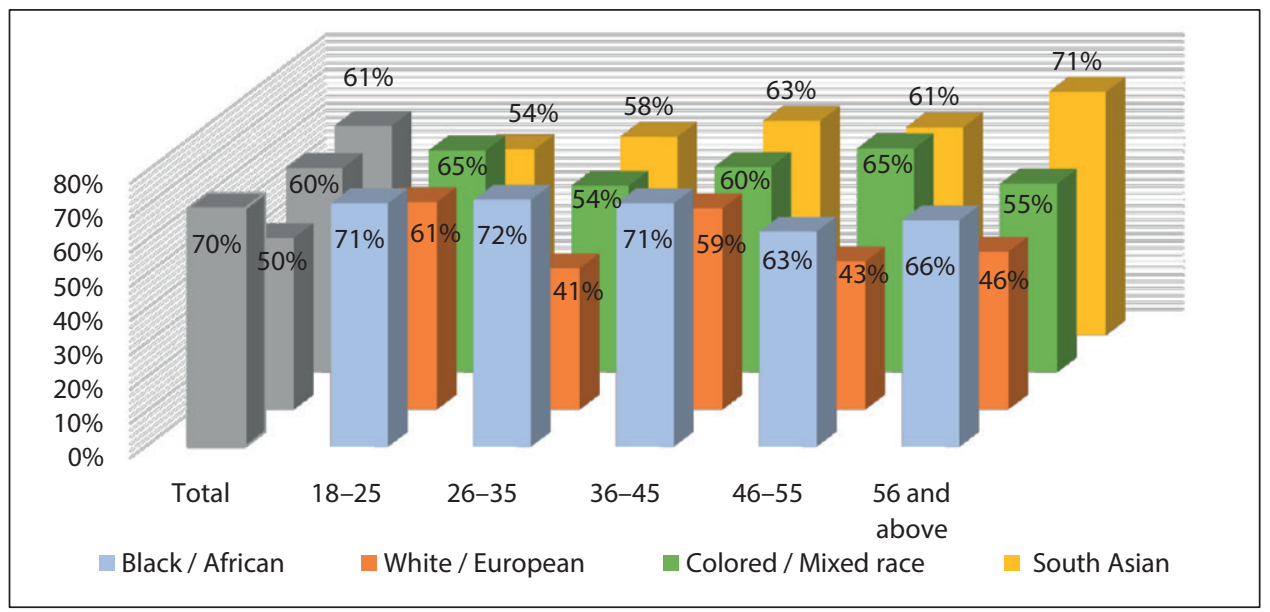

Figure 6: Support for Democracy by Race and Age Source: Afrobarometer R6 2014/2015 online analysis. 


\section{Support for Democracy}

Stability of a democratic society depends on how much people believe that democracy is the "only game in town". If there is a solid trust in democracy as the best possible regime, society can afford a bit of dissent, mistrust in institutions and leaders, even protests, strikes, and other types of elite-challenging behavior, previously considered unconventional. In South Africa, research shows that less than by education or socialization, support for democracy is most influenced by instrumental evaluation of the performance of the democratic regime and its institutions, and primacy of political over economic evaluations (Mattes, 2011; Diamond, 1990; de Jager \& Adams-Jack, 2017). Support for democracy is highest among the young population, and particularly among the Black African young adults, if not significantly.

As Mattes points out, when race, location (urban vs. rural) and social class are added, generational differences disappear altogether. Those, who have experienced corruption and material insecurity directly are less willing to endorse democracy (Mattes, 2011). Support for democracy among the Born Frees has risen to 74\% in 2011/2012, and declined again to $66 \%$ in 2014, which is likely the result of the impact of instrumental evaluation of political performance in the aftermath of the economic crisis, corruption scandals, and rising tuition fees.

\section{Political Participation}

While the Born Free generation may not differ in terms of their political orientations and beliefs on average, they do tend to participate or support political participation that was previously considered unconventional (de Jager \& Adams-Jack, 2017).

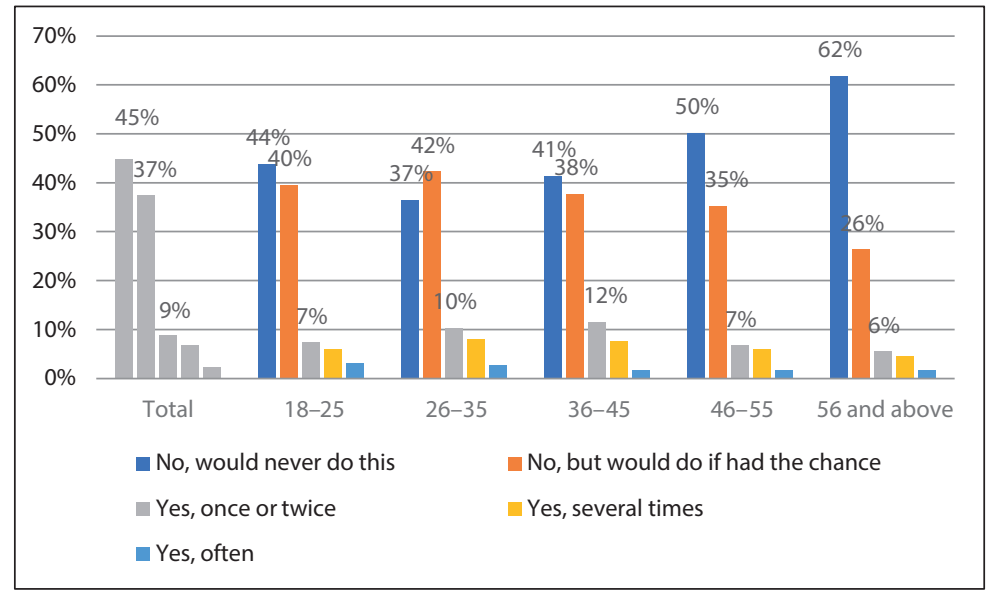

Figure 7: Attend a Demonstration or a Protest March Source: Afrobarometer R6 2014/2015 
Data collected in 2015 show that the Born Frees, but especially the younger adults in the age group between 26 to 35 years of age are most inclined to participate in such activities. In 2017, the numbers have not changed much $-26.7 \%$ of South Africans reported that they have attended a demonstration or protest march and $25.3 \%$ indicated that they would attend such a march should they get the chance to do so - 52\% total (Potgieter, 2017) compared to $56 \%$ in 2014/2015 in the Afrobarometer survey.

\section{Fees Must Fall: The Rise of Elite-Challenging Behavior}

The \#RhodesMustFall movement arose on university campuses amongst the shadows of the apartheid and colonial past. The first generation of black students, while physically included in the education system, faced gaping disparities between their lives and those of their white counterparts on the daily basis. Often not able to afford a dormitory, they commuted each day from the townships to the splendid halls of historically white universities. Rather than gratitude for the opportunity, they experienced humiliation and frustration (Ray, 2016). When student Chumani Maxwele desecrated a centrally located Cecil Rhodes statue at the University of Cape Town by pouring human waste on it in March 2015, it became a symbol around which these sentiments could rally. The first wave of the \#FeesMustFall protests arose from protesting the announced hike in the tuition fees. Students united across the dividing lines and voiced their dissent on majority of campuses. Soon, they spilled over to other traditionally white universities, inspiring campaigns as \#OpenStellenbosch and \#AfrikaansMustFall, \#WitsFeesMustFall, and several others. At times, however, they became disruptive and violent. They have threatened the completion of the academic year 2016/2017 at many universities across South Africa and sharply divided the society. The 2016 SARB survey shows that $43 \%$ of South Africans strongly agreed or agreed that the \#FeesMustFall protests were justified, while 38\% disagreed or strongly disagreed (Potgieter \& Govender, 2016, p. 12). They have divided students and faculty at universities. Many were quick to dismiss the protests as exaggerated and unreasonable. As a result, Christo Thesnaar explains, students and other young activists reported feeling unheard and disrespected. This added to the continued frustration of exclusion. The generation of anti-apartheid activists are now the leaders, having a strong base of loyalty among older people. But the students do not feel they owe them such loyalty. "The government is full of old people and the next generation is not included" (personal interview, January 26, Stellenbosch).

Students achieved freezing of the raises in tuition fees, more support for students in need, platforms for negotiation with universities leadership, limits on outsourcing, etc. President Zuma promised free education to most students in December 2017 (leaving his successor to scramble a plan for implementation). Furthermore, protests have demonstrated the investment of the young educated population in their society - the vehemence of the protests caught many off-guard, being the largest protests since 1980s and openly claiming the heritage of the anti-apartheid student struggle. The movement successfully placed 
several issues on the table, some for the first time: questions related to gender equality, patriarchy, LGBTQ community rights, decolonization of the university curricula, etc., which continue to be raised even after the protests ceased. The protests triggered a broader Fallist movement, \#ZumaMustFall, \#SaveSA or \#UniteBehind, which centered around civil society actors, inspired by the students' use of social media. The protests and the use of the hashtag label emitted a signal of a united front against the status quo, broader than any particular population group, and Zuma did eventually fall, as did the fees.

\section{Eureka?}

From the point of view of comparative political science research, conclusion is usually reached at around this point in the analysis. Reasonably high level of support for democracy among the young, combined with low trust in specific political institutions and leaders, and the rise of elite-challenging political participation signal the rise of "critical" or "assertive" citizens in South Africa. Thus, not a generational change, but a more global trend in rising assertive citizenship is to explain the changing political participation in South Africa. However, that is an overly confident conclusion to reach. The construction of generational identity narratives is more nuanced than to be seen through national averages in public opinion polls. Sociology of generations underscores the construction of generational consciousness around significant events and strong political emotions - not every era has to produce a generation and some eras may lead to multiple generational units (Mannheim, $1972(1928))$.

\section{Support for Political Community}

As we have seen so far, public opinion surveys from 2015-2017 do not, in general, show significant differences between generations. "Contrary to popular wisdom, there is virtually no "age profile" to democratic citizenship in South Africa. In terms of their perceptions of their role and their capacity as citizens, youth look almost identical to their older counterparts" (Mattes \& Richmond, 2015). Even when moving to the last, diffuse level of political support, we will not find great differences between generations in the aggregated data. The young South Africans do feel primarily South African or equally South African and belonging to their ethnic community. Same is true across all racial groups, and is particularly strong in the White and Black African population.

Yet when observing the public discourse in the media since the beginning of the student protests, there is a widespread perception of an emerging generational consciousness and of an identity crisis, which divides communities and even families. Albie Sachs, one of the authors of the Bill of Rights and former judge at the Constitutional Court of South Africa, reflects on the paradox of the Born Frees challenging the transitional narrative: "It is fantastic that the students are raising these issues. There's a new energy, there's idealism there's a new 


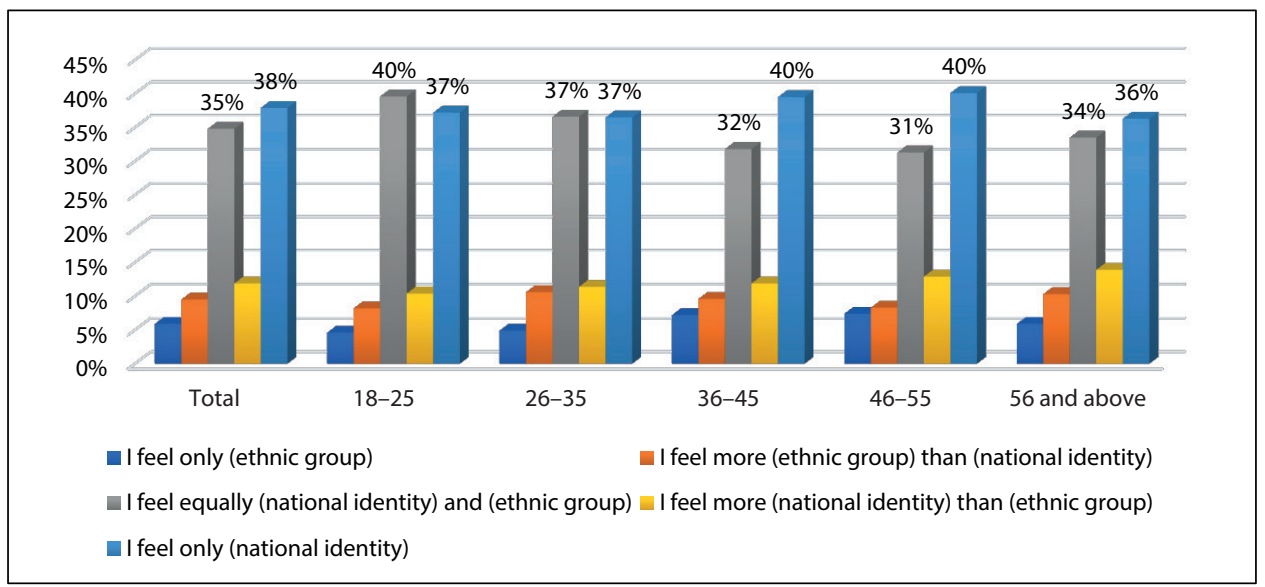

Figure 8: Preference of Ethnic or National Identity

Source: Afrobarometer R6 2014/2015 online analysis

vitality. But there's a huge contradiction at the centre of what they are doing. Because they are called Born Frees, although they are not free. But they are speaking as free people...And in a sense it is tribute to the nature and the depth of the change that students are not even aware of how bad it was" (pers. interview, January 9, 2017, Clifton). Helen Scanlon sees the protests as "definitely a generational issue... A lot of [the students] were telling me how they face resistance from their parents, even those that were a part of the Soweto movement in 1976. And they were furious with them. They are not understanding and actually rejecting their generation. If you've seen any posters, there was one that said, 'We were sold a dream in 1994, we're here for the refund!' So this is a totally different generation" (personal interview, January 23, UCT, Cape Town).

\section{Dismantling the Rainbow Nation?}

The student movements have had other significant impact on the South African society. Its reconciliation process has been fragile and incomplete. The movements have directly or indirectly opened several unresolved questions and challenged the very foundations of the young democracy. The student movement itself is figuring out its relationship to the founding messages of the new regime. While many are denying or challenging the concept of a Rainbow Nation at present, they differ in the vision the movement should strive toward. Many of the vocal activists subscribe to icons as Steve Biko, ideas of Frantz Fanon and traditions of Black Consciousness movement, decolonial thought, Pan-Africanism, rather than to unifying personalities as Oliver Tambo or Nelson Mandela and their philosophy of non-racialism and reconciliation. They harken back to Thabo Mbeki's thesis of the two nations (one prosperous settler nation, and the other the impoverished native nation) 
(Chikane, 2018, s. 21), which he presented during his Presidency in 1998, proclaiming the failure of reconciliation. Jackie Shandu, activist and a former provincial leader of the EFF represents the more radical voice of the movement which rejects the message of the former anti-apartheid struggle altogether: "Mandela sold out the Freedom Charter, he was state managed" (Indaba with Alex Mthiyane, Dec. 15, 2015). Many students from the leadership of hashtag movements concur, if in less radical language. The Rainbow Nation is presented as a false consciousness (borrowing from Marx and Engels) that serves to disguise the real disparities and continuing oppression.

The change involved a return to civil disobedience of past defiance campaigns that helped end apartheid. The shift in youth politics in South Africa can be attributed to the change from the dominant narrative of a Rainbow Nation, towards a narrative that acknowledges that the compromises made to create a racially unified country came at the expense of human restitution and economic redistribution linked to Apartheid's past injustice. It is an economic divide that continues to marginalize black and colored racial groups in the country (Chikane, 2018, p. 23).

Student Ziyana Lategan explains that the main goal of the movement is decolonization. "The negotiated transition is a cliché, so boring to even think about. ANC has sold the nation. The Rainbow Nation evaporated gradually and died with the Marikana Massacre" (public discussion, Stellenbosch University, July 27, 2017), when the SA police brutally suppressed protest of miners with gunfire, killing 34 . Other students, however, see the Constitution as essentially right, but the transition process as failed to implement its promise.

There is a sharp resistance, however, from the young people who are not university students and not from urban centers. A self-described rural tribalism voice rejects the labels of different races in the name of universal humanism. They ask, if the Rainbow Nation is not to exist, what shall exist in its place? "And if we refuse to be Black, what does that make us?" (pers. interview, July 27, Stellenbosch). They sometimes doubt the students' motivation and point out to the privileged position of the university students, detached from the real problems of the communities they came from (personal interview with Pumla GobodoMadikizela, Jena, October 30,2017). The young generation is fractured in their attitude toward the past legacies and vision of a political nation.

Student voices are a small part of the university student population, which, in turn, represents just over one tenth of the young generation altogether. But while the voices calling for the dismantling of the notion of the Rainbow Nation and proclaiming it dead at birth or broken by the student movements are not numerous, they are loud, and they stir strong emotions in the broader public. The challenge to the idea of the Rainbow Nation is heard loud and clear. It is a cry against social and economic inequality, dissociated from the founding symbols of post-1994 South Africa. Generational gap is perceived as serious and calls for a new, intergenerational public reconciliation dialogue (pers. interview with C. Thesnaar). 
Among some of the former anti-apartheid struggle and liberation leaders, there was a sense of shock and disbelief at the ungratefulness of the young for all that has been achieved since the fall of the apartheid. Many were conspicuously silent on the matter of student protests, or voiced their disagreement with them. Others were sympathetic with the cause, though in disagreement with the rejection of the liberation movement's message. Almost all interviewed from the Struggle generation expressed a deep sense of misunderstanding of the past on the part of the student protesters. Denis Goldberg, who was arrested together with Nelson Mandela and imprisoned for 22 years, blames ignorance: “The young don't know what apartheid was like... So the children not only don't know about the transition, they accuse Nelson Mandela of selling us out. But they do not recognize that in the four years after he was released till the time he became president, between ten thousand and twelve thousand people were murdered. Our young people today don't know and don't care that the need of the leadership led by Nelson Mandela was to put a stop to violence. (personal interview, January 25, 2017, Hout Bay). Njabulo Ndebele also believes the quality of education, the way it fails to address race in meaningful way, is among the main causes for intergenerational disjuncture. Education should confront the past and create a shared intellectual culture (Ndebele, 2016).

\section{Democratic prospects for South Africa}

There are some conditional reasons for optimism. Some of the them depend on the way the young generation will shape its narrative about the past. South Africa is founded on a profoundly democratic Constitution, which has given rise to a net of strong independent institutions, and both are broadly supported by all segments of the population. Its creation in $21^{\text {st }}$ century builds on half a century of experience of struggle against oppression and places advanced human rights principles at its core. The decades of anti-apartheid struggle have produced a foundation for a vibrant civil society, albeit marked by the strong legacy of violence. There was a growing opposition to the populist rule and to the abuse of power by the President and his "keepers" from within and outside of the ANC (Calland, 2016, pp. 146-147). Even though the ANC has been the ruling party since 1994, there is a solid spectrum of political parties and free and fair elections are the established rule of the game (du Preez, 2013,pp. 264-270). The new generation, Calland points out, also represents hope for optimistic future by demonstrably caring, striving to be heard, and by taking action against the misuse of power (Calland, 2016).

The Born Frees do represent a generation of "assertive citizens". They are more educated than their parents and grandparents, they do follow politics, and do take part in the political process (if not necessarily through electoral turnout). Unlike their equally (or more) disenchanted parents and grandparents, they are, however, more likely to challenge their governments through unconventional modes of political participation, utilizing social networks for fast and effective political mobilization. The hashtag movements have been 
able to push for changes which were before deemed difficult if not impossible to achieve. De Jager and Adams-Jack importantly point out this boost in political competence must be taken seriously, as it has consequences for how we evaluate democratic participation and civic culture as such (de Jager \& Adams-Jack, 2017).

The future success of South Africa's democratic project depends on amelioration of social and economic inequalities and taking accountability seriously. While there is no significant generational change noticeable in sociological surveys, there is a widely perceived generational divide and a growing fracture in collective memory, challenging the very foundations of democratic South Africa. The success of the democratic project rests also on the condition that the national project of the Rainbow Nation survives. Time is ripe for a second round of reconciliation, a public discussion across the generations, and opening of the official narrative to make space for voices suppressed from it. Otherwise the Born Free generation, emotionally disconnected from that narrative and from previous generations will continue to be fragmented within, and detached from the imagined community of South Africans, radicalized by years of marginalization, inequality, and ignorance.

\section{References}

Calland, R. (2016a). Make or Break: How the next three years will shape South Africa's next three decades. Cape Town, South Africa: Penguin Random House.

CHE. (2018). Vital Stats: Public Higher Education in 2016. Retrieved Aug 30, 2018, from Council on Higher Education South Africa: http://www.che.ac.za/sites/default/files/publications/CHE_VitalStats_2016\%20webversion_0.pdf

Cherry, J. (2017, June 29). The successes and failures of South Africa's student movement. Retrieved from

Waging Non-Violence: https://wagingnonviolence.org/feature/south-africa-fees-must-fall/

Chikane, R. (2018). Young People and the \#Hashtags That Broke the Rainbow Nation. In S. Pickard, \& J. Bessand (Eds.), Young People Re-Generating Politics in Times of Crises (pp. 19-40). Cham, Switzerland: Palgrave Macmillan.

Almond, G., \& Verba, S. (1963). The Civic Culture: Political Attitudes in Five Western Democracies. Princeton, New Jersey.

Asmal, K. (2011). Politics in my blood: A memoir. Auckland Park, South Africa: Jacana Media (Pty) Ltd.

Dalton, R. J., \& Welzel, C. (Eds.). (2014). The Civic Culture Transformed: From allegiant to assertive citizens. Cambridge, MA: Cambridge University Press.

de Jager, N., \& Adams-Jack, U. (2017). Stellenbosch University's Born-Frees: Responsibly engaged. In

D. Lambrechts, \& P. Fourie (Eds.), Modern State Development, Capacity, and Institutions (pp. 137-148).

Stellenbosch: SUN MeDIA.

Diamond, L. (1990). Developing Democracy: Toward Consolidation. Baltimore and London: The John Hopkins University Press.

du Preez, M. (2013). A Rumour of Spring: South Africa after 20 years of democracy. Cape Town: Zebra Press. Easton, D. (1975). A Reassessment of the Concept of Political Support. British Journal of Political Science, $5(4), 435-457$.

Fairbanks, E. (2015, November 18). Why South African students have turned on their parents' generation. 
Retrieved from The Guardian: https://www.theguardian.com/news/2015/nov/18/why-south-africanstudents-have-turned-on-their-parents-generation

Gqubule, T. (2017). No Longer Whispering to Power: The Story of Thui Madonsela. Jeppestown, South Africa: Jonathan Ball Publishers.

Hodgkin, K., \& Radstone, D. (2003). Regimes of Memory. London, New York: Routlege.

Indaba with Alex Mthiyane. (Dec. 15, 2015). Gagasi FM.

Inglehart, R., \& Catterberg. (2002, Oct 1). Trends in Political Action: The Developmental Trend and the Post-Honeymoon Decline. Journal of International Comparative Sociology, 43(3-5), 300-316.

Ipsos. (2018a, July 17). Ipsos Poll: ANC support at 60\%. Retrieved Sept 5, 2018, from Ipsos: https://www. ipsos.com/en-za/ipsos-poll-anc-support-60

Ipsos. (2018b, Aug 17). South Africans rate Cyril Ramaphosa. Retrieved Sept 5, 2018, from Ipsos: https:// www.ipsos.com/en-za/south-africans-rate-cyril-ramaphosa

Johnson, R. (2017). How Long Will South Africa Survive? The Crisis Continues ( $2^{\text {nd }}$ Edition ed.). Johannesburg \& Cape Town, South Africa: Jonathan Ball Publishers (Pty) Ltd.

Mattes, R. (2011). The "Born Frees": The Prospects for Generational Change in Post-Apartheid South Africa. Cape Town: Afrobarometer.

Mattes, R., \& Richmond, S. (2015, Jan). Are South Africa's youth really a 'ticking time bomb'? (M. Bratton, Ed.) Afrobarometer, p. 25.

Mishler, W., \& Rose, R. (2001). What Are the Origins of Political Trust?: Testing Institutional and Cultural Theories in Post-communist Societies. Comparative Political Studies, 34(1), 30-61.

Ndebele, N. (2016, September 17). They Are Burning Memory. Retrieved from Njabulo Ndebele blog: www. njabulondebele.co.za/author/njabulo-s-ndebele-2/

Norris, P. (1999). Introduction: The growth of critical citizens. In P. Norris (Ed.), Critical Citizens: Global support for democratic government (pp. 1-30). Oxford, England: Oxford University Press.

Nyoka, A., \& Lekalake, R. (2015, June 15). Improving Prospects for South Africa's Youth: Education, vocational training still key priorities. Afrobarometer Dispatch No. 36.

Potgieter, E. (2017). SA Reconciliation Barometer Survey: 2017 Report . Institute for Justice and Reconciliation. Cape Town: Institute for Justice and Reconciliation.

Potgieter, E., \& Govender, R. (2016). 20 Years of the SA Constitution: People, Institutions, and Rights. SA Reconciliation Barometer, Institute for Justice and Reconciliation, Cape Town.

Ramphele, M. (2010). Laying Ghosts to Rest: Dilemmas of the transformation in South Africa ( $5^{\text {th }}$ printing ed.). Pietermaritzburg, South Africa: Tafelberg.

Ray, M. (2016). Free Fall: Why South African Universities are in a Race Against Time. Johannesburg, South Africa: Bookstorm.

Southall, R. (2016). The New Black Middle Class in South Africa. Auckland Park, South Africa: Jacana Media (Pty) Ltd.

Statistics South Africa. (2017, June 1). Quarterly Labour Force Survey Quarter 1 2017. Retrieved Aug 10, 2017, from Stats SA: http://www.statssa.gov.za/?p=9960

Swartz, S. (2016). Another Country: Everyday Social Restitution. Cape Town, Western Cape, South Africa: HSRC Press.

The World Bank. (2018). GINI Index. Retrieved from The World Bank: http://databank.worldbank.org/ data/reports.aspx ? source $=2 \&$ series $=$ SI.POV.GINI\& country $=\#$

UNDP. (2016). Human Development for Everyone. Briefing note for countries on the 2016 Human Development Report: South Africa. Retrieved from United Nations Development Programme Human Development Reports: http://hdr.undp.org/sites/all/themes/hdr_theme/country-notes/ZAF.pdf 
Wa Azania, M. (2016). Memoirs of a Born Free: Reflections on the Rainbow Nation (Sixth impression ed.). Auckland Park, South Africa: Jacana Media (Pty) Ltd.

\section{Author}

\section{Dagmar Kusá}

Bratislava International School of Liberal Arts.

Contact details: Grösslingova 53, Bratislava 81109, Slovak Republic; e-mail: kusa@bisla.sk 